\title{
Analisa Rumah Sederhana Sehat Terhadap Kenyamanan Ruang (Studi Kasus: Rumah Tipe 18/24, 22/60, 36/72 di DKI Jakarta)
}

\author{
Room Comfort Analysis of Simple-Healthy Houses \\ (Case Study: Houses Type 18/24, 22/60, 36/72 in DKI Jakarta)
}

\author{
Randy Dwiyan Delyuzir ${ }^{1}$ \\ ${ }^{1}$ Arsitektur, Universitas Tanri Abeng \\ Email: randy.delyuzir@tau.ac.id
}

\begin{abstract}
Abstrak
Penelitian ini bertujuan untuk menganalisa standard rumah sehat dan kenyamanan ruang pada 3 tipe rumah tangga di DKI Jakarta. Sampel pengukuran yaitu 3 tipe rumah tangga di DKI Jakarta $(18 / 24,22 / 36$ \& 36/72), berdasarkan data dari BPS DKI Jakarta, sebanyak 58.09\% rumah tangga di DKI Jakarta dengan luasan $<19-49$ $\mathrm{m}^{2}$. Metode yang digunakan adalah kualitatif melalui observasi dan studi literatur. Pada tipe 18/21 dan 22/36 belum memiliki sarana pembuangan asap pada area dapur, tipe 36/72 area dapur sudah memiliki sarana pembuangan asap pada belakang rumah. Luas sirkulasi pada tipe 18/21 sebesar $9 \mathrm{~m}^{2}$ atau $50 \%$ dari luas lantai dan luas perabot $3.7 \mathrm{~m}^{2}$ atau $20.5 \%$ dari luas lantai. Luas sirkulasi tipe 22/36 sebesar $12.5 \mathrm{~m}^{2}$ atau $56.8 \%$ dari luas lantai dan luas perabot $4.3 \mathrm{~m}^{2}$ atau $19.7 \%$. Luas sirkulasi tipe $36 / 72$ sebesar $21.5 \mathrm{~m}^{2}$ atau $59.7 \%$ dari luas lantai dan luas perabot $10.2 \mathrm{~m}^{2}$ atau $28.3 \%$ dari luas lantai.
\end{abstract}

Kata kunci: kenyamanan ruang, rumah sederhana sehat, sirkulasi, pencahayaan, penghawaan

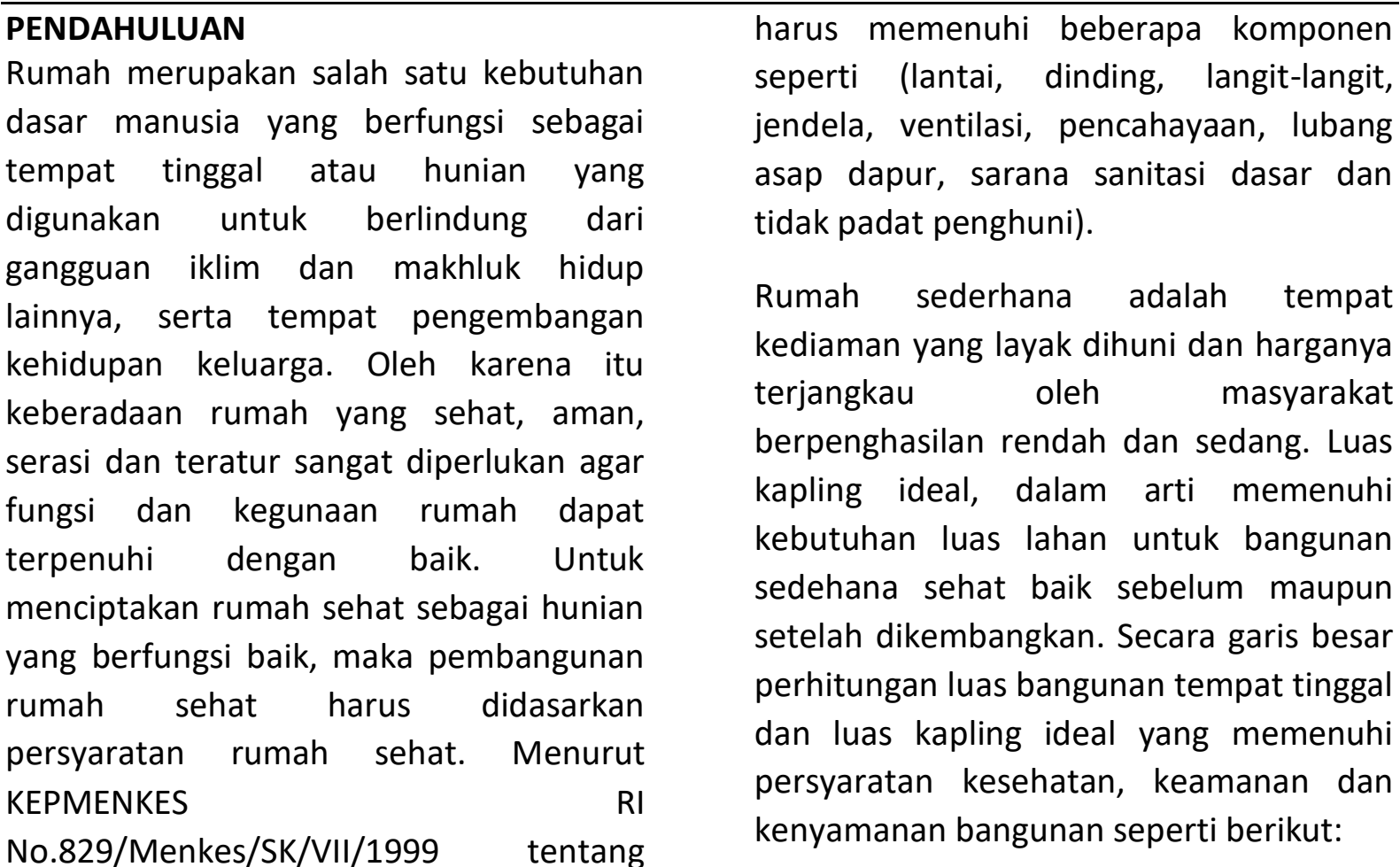

Persyarataan Kesehatan Perumahan, 
- Kebutuhan ruang minimal menurut perhitungan dengan ukuran standar minimal adalah $9 \mathrm{~m} 2$, atau standar ambang dengan angka 7,2 m2 per orang. Sebagai konsepsi dasar kedua perhitungan tersebut masih digunakan dengan tetap mempertimbangkan bentuk akhir rumah pasca pengembangan. Sehingga dari hasil perhitungan diatas didapat luas bangunan awal (RIT) adalah 21m2 dengan pertimbangan dapat dikembangkan menjadi $36 \mathrm{~m} 2$ bahkan pada kondisi tertentu dimungkinkan memenuhi standar ruang international. (Keputusan Menteri Permukiman dan Prasarana Wilayah Republik Indonesia, 2002)

Rumah Sederhana Sehat (RSh) yaitu rumah yang dibangun dengan menggunakan bahan bangunan dan konstruksi sederhana, akan tetapi masih memenuhi standar kebutuhan minimal dari aspek kesehatan, keamanan, dan kenyamanan, dengan mempertimbangkan dan memanfaatkan potensi lokal meliputi potensi fisik seperti bahan bangunan, geologis dan iklim setempat serta potensi sosial budaya seperti arsitektur lokal, dan cara hidup. (Keputusan Menteri Permukiman dan Prasarana Wilayah Republik Indonesia, 2002)

Rumah sehat menurut Kasjono, 2011 adalah tempat berlindung/bernaung dan tempat untuk beristirahat sehingga menumbuhkan kehidupan yang sempurna baik fisik rohani maupun sosial.
Adapun ketentuan persyaratan kesehatan rumah tinggal menurut Kepmenkes No.

829/Menkes/SK/VII/1999 adalah sebagai berikut :

1. Bahan bangunan

a. Tidak terbuat dari bahan yang dapat melepaskan bahan yang dapat membahayakan kesehatan, antara lain : debu total kurang dari $150 \mu \mathrm{g} / \mathrm{m}^{2}$, asbestos kurang dari $0,5 \mathrm{serat} / \mathrm{m}^{3}$ per $24 \mathrm{jam}$, plumbum (Pb) kurang dari $300 \mathrm{mg} / \mathrm{kg}$ bahan.

b. Tidak terbuat dari bahan yang dapat menjadi tumbuh dan berkembangnya mikroorganisme patogen.

2. Komponen dan penataan ruangan

a. Lantai kedap air dan mudah dibersihkan.

b. Dinding rumah memiliki ventilasi, kamar mandi dan kamar cuci kedap air dan mudah dibersihkan.

c. Langit-langit rumah mudah dibersihkan dan tidak rawan kecelakaan.

d. Bumbungan rumah $10 \mathrm{~m}$ dan ada penangkal petir.

e. Ruang ditata sesuai dengan fungsi dan peruntukannya.

f. Dapur harus memiliki sarana pembuangan asap.

3. Pencahayaan

a. Pencahayaan alam dan/atau buatan langsung maupun tidak langsung dapat menerangi seluruh ruangan dengan intensitas penerangan minimal 60 lux dan tidak menyilaukan mata.

4. Kualitas udara

a. Suhu udara nyaman antara 18$30^{\circ} \mathrm{C}$.

b. Kelembaban udara $40-70 \%$.

c. Gas SO2 kurang dari 0,10 ppm/24 jam.

d. Pertukaran udara 5 $\mathrm{kaki}^{3} /$ menit/penghuni. 
e. Gas CO kurang dari 100 ppm/8 jam.

f. Gas formaldehid kurang dari 120 $\mathrm{mg} / \mathrm{m}^{3}$.

5. Ventilasi

a. Luas lubang ventilasi alamiah yang permanen minimal $10 \%$ luas lantai.

6. Vektor penyakit

a. Tidak ada lalat, nyamuk ataupun tikus yang bersarang di dalam rumah.

7. Penyediaan air

a. Tersedia sarana penyediaan air bersih dengan kapasitas minimal 60 liter/orang/hari;

b. Kualitas air harus memenuhi persyaratan kesehatan air bersih dan/atau air minum

menurut Permenkes no. 416 tahun 1990 dan Kepmenkes no. 907 tahun 2002.

8. Sarana penyimpanan makanan

a. Tersedia sarana penyimpanan makanan yang aman.

9. Pembuangan Limbah

a. Limbah cair yang berasal rumah tangga tidak mencemari sumber air, tidak menimbulkan bau, dan tidak mencemari permukaan tanah.

b. Limbah padat harus dikelola dengan baik agar tidak menimbulkan bau, tidak mencemari permukaan tanah dan air tanah.

10. Kepadatan hunian

a. Luas kamar tidur minimal $8 \mathrm{~m}^{2}$ dan dianjurkan tidak untuk lebih dari 2 orang tidur.

Aspek kenyamanan pada bangunan terbagi menjadi 4 yaitu kenyamanan ruang, kenyamanan visual, kenyamanan audio dan kenyamanan termal. (Karyono, 1999)
Aspek kenyamanan ruang dipengaruhi oleh kenyamanan ruang gerak dan kenyamanan hubungan antar ruang.

Aspek kenyamanan visual peroleh dari tata massing, desain bukaan, tata ruang interior dan eksterior, dan pengunaan area ruang luar bangunan, rekayasa pencahayaan serta pemilihan warna dan material pada elemen interior.

Kenyamanan termal dipengaruhi oleh aktivitas, kebudayaan, adat istiadat dan persepsi orang terhadap suhu, kelembaban dan iklim. Dari hasil penelitian terhadap siswa Sekolah Dasar Negeri Ulujami 02, di Jakarta Selatan didapatkan suhu nyaman adalah 30,20 -C suhu udara $\left(T_{a}\right)$. (Delyuzir \& Murni, 2019)

Kenyamanan audio dilihat berdasarkan kenyamanan terhadap kebisingan baik di dalam bangunan maupun lingkungan. (Permen PU No. 28 Tahun 2002)

Tidak terpenuhinya aspek tersebut pada sebuah ruang akan menyebabkan kegiatan manusia dalamnya menjadi tidak optimal, dan menandakan bahwa proses perancangan ruang/gedung tersebut kurang berhasil. (Kusumaningrum , 2017)

Dari paparan di atas maka permasalahan penelitian;

1. Apakah 3 tipe rumah tangga di DKI Jakarta sudah memenuhi syarat rumah sehat?

2. Apakah 3 tipe rumah tangga di DKI Jakarta sudah nyaman secara ruang?

Tujuan penelitan ini untuk menganalisa apakah 3 tipe rumah tangga di DKI Jakarta sudah memenuhi syarat rumah sehat dan nyaman secara ruang. Batasan penelitian meliputi Komponen Penataan Ruang, 
Pencahayaan, Ventilasi dan Kepadatan Hunian.

\section{METODE PENELITIAN}

Kajian kenyamanan ruang rumah sederhana sehat dilakukan dengan metode kualitatif melalui observasi dan studi literatur. Untuk mendapatkan syarat rumah sehat dan nyaman ruang, komponen yang dijadikan variable adalah; standar rumah sehat, pencahayaan, penghawaan, sirkulasi dan perabot. Lokasi penelitian berada di DKI Jakarta, berdasarkan data presentase rumah tangga di DKI Jakarta, Luas Lantai Rumah Terluas $\left(\mathrm{m}^{2}\right)$ menurut Badan Pusat Statistik DKI Jakarta, sebanyak 58.09\% rumah tangga di DKI Jakarta yang mempunyai luas $<19-49 \mathrm{~m}^{2}$, peneliti membagi 3 luasan yang banyak dimiliki di DKI Jakarta untuk memudahkan dalam menganalisa, antara lain 18/24, 22/36, dan 36/72 dalam $\mathrm{m}^{2}$.

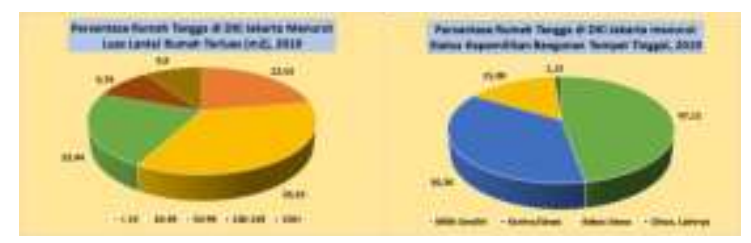

Gambar 1. Presentase Luas Lantai $\left(\mathrm{m}^{2}\right)$ Rumah Tangga di DKI Jakarta,

Sumber: BPS DKI Jakarta.

\section{Subjek Penelitian}

Subjek penelitian ini adalah 3 tipe rumah tangga yang dimiliki sebanyak $58.09 \%$ di DKI Jakarta, yaitu tipe 18/24, 21/36, dan $36 / 72$. Penentuan subjek dalam penelitian ini dilakukan secara non probability sampling, yaitu sampling purposive. Metode yang digunakan dalam pengambilan sampel secara non probability sampling dengan metode sampling purposive didasarkan atas ciriciri tertentu yang dipandang mempunyai sangkut paut yang erat dengan ciri-ciri

populasi yang sudah diketahui sebelumnya.

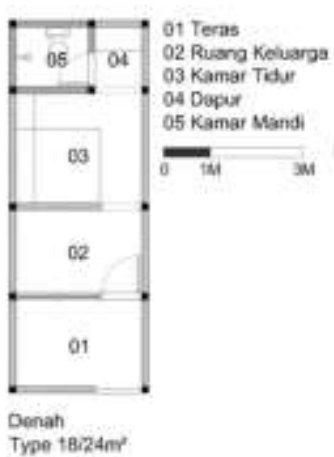

Gambar 2. Rumah Tipe 18/24 Sumber: Peneliti, 2020
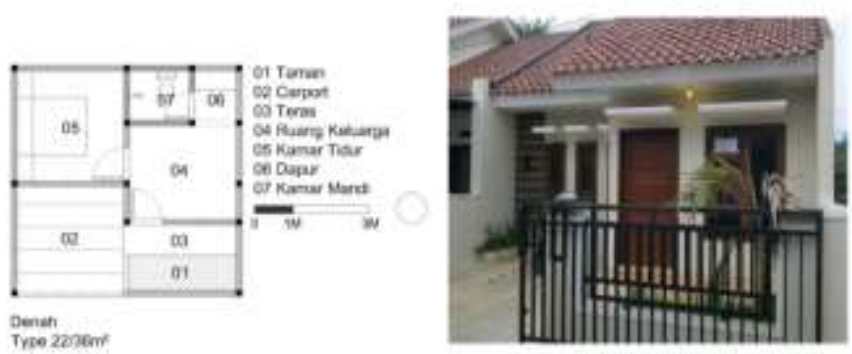

Gambar 3. Rumah Tipe 21/36

Sumber: Peneliti, 2020
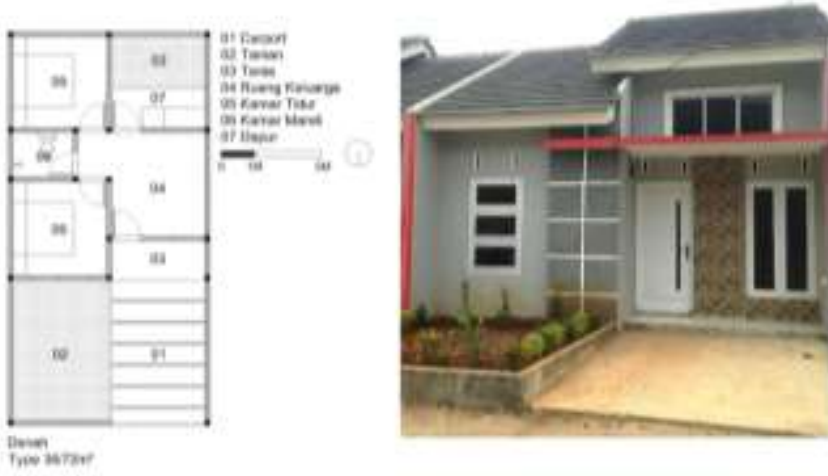

Gambar 4. Rumah Tipe 36/72 Sumber: Peneliti, 2020

\section{Pengumpulan Data}

Teknik pengumpulan data materi penelitian meliputi materi fisik dan nonfisik. Materi fisik didapatkan berdasarkan pengamatan dan pengukuran. Sedangkan materi non fisik didapatkan dari hasil wawancara untuk 
mendapatkan kenyamanan ruang secara kualitatif. Obyek penelitian adalah rumah sederhana dengan luasan $<19-49 \mathrm{~m}^{2}$, dengan studi kasus 3 tipe rumah 18/24, $22 / 36$ \& $36 / 72$ dalam $\mathrm{m}^{2}$.

\section{Metode Pengolahan Data}

3 tipe rumah tangga di DKI Jakarta, dianalisa berdasarkan syarat standar rumah sehat dari Kepmenkes No. 829/Menkes/SK/VII/1999, kemudian data standar rumah sehat dibandingkan dengan hasil observasi 3 tipe rumah tangga di DKI Jakarta. Selanjutnya 3 tipe rumah dianalisa berdasarkan kriteria standar rumah sehat dan nyaman ruang. Kenyamanan ruang yang dibahas dalam penelitian ini meliputi 3 hal yaitu; kenyamanan ruang berdasarkan Pencahayaan dan Penghawaan, kenyamanan ruang berdasarkan Sirkulasi dan kenyamanan ruang berdasarkan Penataan Perabot.

\section{PEMBAHASAN}

Rumah sederhana sehat yang menjadi objek penelitian dipilih karena karekteristik bangunan yang unik dan sebanyak $58.09 \%$ mempunyai luas <19-
$49 \mathrm{~m}^{2}$ di rumah tangga DKI Jakarta berdasarkan data dari BPS DKI Jakarta. Rumah sederhana sehat harus memenuhi persyaratan sebagai hunian dan disisi lain harus memenuhi kebutuhan penghuni yang berkembang seiring waktu. Rumah sederhana sehat disamping harus memenuhi persyaratan rumah sehat juga harus mempertimbangkan kenyamanan penghuninya. Kenyamanan ruang yang dirasakan oleh penghuni dipengaruhi oleh banyak hal dan banyak faktor. Pada tabel 1 dibawah ini data analisa perbandingan persyaratan rumah sehat dengan 3 tipe rumah tangga di DKI Jakarta.

Dari persyaratan pencahayaan, ventilasi dan kepadatan hunian, seluruh tipe rumah rumah tangga di DKI Jakarta, sudah memenuhi syarat rumah sehat menurut KepMenKes No.829/Menkes/SK/VII/1999.

Terdapat satu komponen yang tidak memenuhi syarat rumah sehat pada tipe $18 / 24$ dan 22/36, komponen yang tidak memenuhi syarat berada pada dapur belum memiliki sarana pembuangan asap, untuk tipe 36/72 dapur sudah memiliki sarana pembuangan asap.

Tabel 1. Persyaratan Rumah Sehat dan 3 Tipe Rumah Tangga di DKI Jakarta

\begin{tabular}{|c|c|c|c|c|}
\hline No & $\begin{array}{l}\text { Persyaratan Rumah Sehat } \\
\text { (KepMenkes No.829/Menkes/SK/VII/1999) }\end{array}$ & Tipe 18/24 & Tipe 22/36 & Tipe 36/72 \\
\hline \multirow[t]{5}{*}{1} & Komponen dan Penataan Ruang & & & \\
\hline & a. Lantai kedap air dan mudah dibersihkan & Sesuai & Sesuai & Sesuai \\
\hline & b. Dinding rumah memiliki ventilasi & Sesuai & Sesuai & Sesuai \\
\hline & c. Ruang ditata sesuai fungsi dan peruntukan & Sesuai & Sesuai & Belum Sesuai \\
\hline & d. Dapur harus memiliki sarana pembuangan asap & Tidak ada & Tidak ada & Ada \\
\hline \multirow[t]{2}{*}{2} & Pencahayaan & & & \\
\hline & $\begin{array}{l}\text { a. Pencahayaan alami maupun buatan dapat } \\
\text { menerangi seluruh ruangan }\end{array}$ & Sesuai & Sesuai & Sesuai \\
\hline \multirow[t]{2}{*}{3} & Ventilasi & & & \\
\hline & $\begin{array}{l}\text { a. Luas lubang ventilasi alamiah yang permanen } \\
\text { minimal } 10 \% \text { dari luas lantai }\end{array}$ & Sesuai & Sesuai & Sesuai \\
\hline \multirow[t]{2}{*}{4} & Kepadatan Hunian & & & \\
\hline & $\begin{array}{l}\text { a. Luas kamar tidur minimal } 8 \mathrm{~m}^{2} \text { dan dianjurkan } \\
\text { tidak untuk lebih dari } 2 \text { orang tidur }\end{array}$ & Sesuai & Sesuai & Sesuai \\
\hline
\end{tabular}




\section{Bangunan Tipe 18/24}

- Rumah tipe $18 / 24$ ditempati 2 orang anggota keluarga (suami \& Istri).

- Terdapat 1 ruang tamu/keluarga, 1 ruang tidur, 1 dapur dan 1 kamar mandi.

- Kondisi pencahayaan rumah tipe $18 / 24$, terdapat pencahayaan alami melalui 1 jendela di ruang tamu/keluarga. Ruang tidur dan dapur mendapat pencahayaan buatan.

- Kondisi penghawaan rumah tipe 18/24, jendela dan pintu berada di depan rumah, hanya ruang tamu/keluarga yang mendapat penghawaan, ruang tidur tidak mendapat penghawaan.

- Area dapur tidak ada sarana pembuangan asap.

- Perabot di rumah tipe 18/24 terdapat 1 kasur, 1 lemari pakaian di kamar tidur dan 1 lemari makan di dapur, penggunaan perabot pada tipe 18/24 hanya di ruang tidur dan dapur.

- Kepadatan hunian luas kamar tidur sebesar $8 \mathrm{~m}^{2}$ dan di isi 2 orang.

\section{Bangunan Tipe 22/36}

- Rumah tipe $22 / 36$ ditempati 3 orang anggota keluarga (Suami, Istri \& 1 Anak).

- Terdapat 1 ruang tamu/keluarga, 1 ruang tidur, 1 dapur dan 1 kamar mandi.

- Kondisi pencahayaan rumah tipe 22/36, terdapat pencahayaan alami melalui 1 jendela di ruang tamu/keluarga dan 1 jendela di kamar tidur, kamar mandi mendapat pencahayaan buatan.

- Kondisi penghawaan rumah tipe 22/36, kamar tidur dan ruang tamu memiliki bukaan yang baik dengan adanya jendela dan pintu utama, kamar mandi tidak mendapat penghawaan.

- Area dapur tidak ada sarana pembuangan asap.

- Kondisi perabot rumah tipe 22/36, terdapat 1 kasur, 1 lemari pakaian di kamar tidur, 4 kursi lipat di ruang tamu/keluarga dan 1 lemari makan di dapur, penggunaan perabot pada tipe 22/36 di area ruang tidur dan ruang tamu.

- Kepadatan hunian luas kamar tidur sebesar $9.7 \mathrm{~m}^{2}$ ditempati untuk 3 orang.

\section{Bangunan Tipe 36/72}

- Rumah tipe $36 / 72$ ditempati 4 orang anggota keluarga (Suami, Istri \& 2 Anak).

- Terdapat 1 ruang tamu/keluarga/makan, 2 ruang tidur, 1 dapur, dan 1 kamar mandi.

- Kondisi pencahayaan rumah tipe $36 / 72$, seluruh ruangan mendapat pencahayaan alami melalui bukaan jendela, hanya kamar mandi yang mendapat pencahayaan buatan.

- Kondisi penghawaan rumah tipe $36 / 72$, seluruh ruangan mendapat penghawaan melalui bukaan jendela dan pintu, kecuali kamar mandi yang tidak mendapat penghawaan.

- Kondisi penataan perabot rumah tipe 36/72, terdapat 2 kasur, 2 lemari 
pakaian di kamar tidur utama dan anak, 1 sofa, 1 meja kecil, 4 kursi makan, 1 meja makan di ruang tamu/keluarga/makan dan 1 lemari makan di dapur, penggunaan perabot tipe 36/72 berada di ruang tamu/keluarga/makan.

- Kepadatan hunian luas kamar tidur sebesar $19.2 \mathrm{~m}^{2}, 2$ kamar tidur dan ditempati 2 orang tiap kamarnya.

\section{Kenyamanan Ruang Berdasarkan Pencahayaan dan Penghawaan}

Menurut Kamus Besar Bahasa Indonesia (KBBI), pencahayaan adalah proses, cara, perbuatan memberi cahaya. Cahaya adalah prasyarat untuk penglihatan manusia terutama dalam mengenali lingkungan dan menjalankan aktifitasnya (Oktavia, 2010: 9). Pada dasarnya objek yang kita lihat adalah pantulan cahaya dari objek tersebut. Oleh sebab itu bagaimana kita melihat dan merespon sekeliling kita sangat tergantung dari jenis pencahayaan yang digunakan.

Pencahayaan memiliki 3 fungsi utama (Code for Lighting 1) yaitu menjamin keselamatan penggunan interior, memfasilitasi performa visual, dan memperbaiki atmosfer lingkungan visual. Pencahayaan yang baik adalah pencahayaan yang memenuhi 3 kebutuhan dasar manusia yaitu kenyamanan visual, performa visual, dan keamanan (Code for Lighting 28). (Dora, P.E. \& Nilasari, 2011)

Penghawaan alami adalah pergantian udara secara alami yang tidak melibatkan peralatan mekanis, seperti mesin penyejuk udara yang dikenal sebagai air conditioner atau AC. (Satwiko, 2009)
Pencahayaan dan penghawaan dalam penelitian ini adalah pencahayaan dan penghawaan alami yang didapat dari terang langit dan udara luar. Idealnya semua ruang mendapatkan pencahyaan dan penghawaan alami secara langsung dengan ukuran sesuai standar Kepmenkes No. 829/Menkes/SK/VII/1999, yaitu luas lubang ventilasi alamiah yang permanen minimal $10 \%$ luas lantai. Namun terdapat beberapa kondisi yang kurang mendukung, seperti permasalahan pada tipe 18/24 dan 22/36 hanya area ruang depan yang mendapat pencahayaan dan penghawaan alami, kamar tidur, kamar mandi dan dapur tidak mendapat pencahayaan dan penghawaan alami, solusinya dibantu dengan pencahayaan buatan seperti lampu, dan pengahwaan buatan pada arah atas bangunan.

Dari 3 tipe kasus rumah yang diteliti didapat bahwa semua rumah sudah memaksimalkan cahaya matahari masuk ke dalam bangunan atau ruang, bentuk ruang tipe 18/24 sudah maksimal dalam penataannya, yang memang mengalami keterbatasan dalam penataan ruang.

Permasalahan utama pada 3 tipe bangunan berada pada kamar mandi, area kamar mandi diapit oleh dua ruang sehingga kurang mendapat pencahayaan alami akan membuat kamar mandi menjadi lembab. Untuk area dapur yang tidak mendapat pencahayaan alami dan penghawaan alami, terdapat pada tipe 18/24 dan 22/36, tidak adanya bukaan pada area dapur mengakibatkan pertukaran udara ketika memasak tidak terjadi, yang mengakibatkan buruknya kualitas udara di dalam ruang.

Untuk seluruh ruang pada 3 tipe rumah tangga di DKI Jakarta, pencahayaan dan penghawaan sudah baik. 
Tabel 2. Analisa Pencahayaan dan Penghawaan 3 tipe Rumah Tangga di DKI Jakarta.

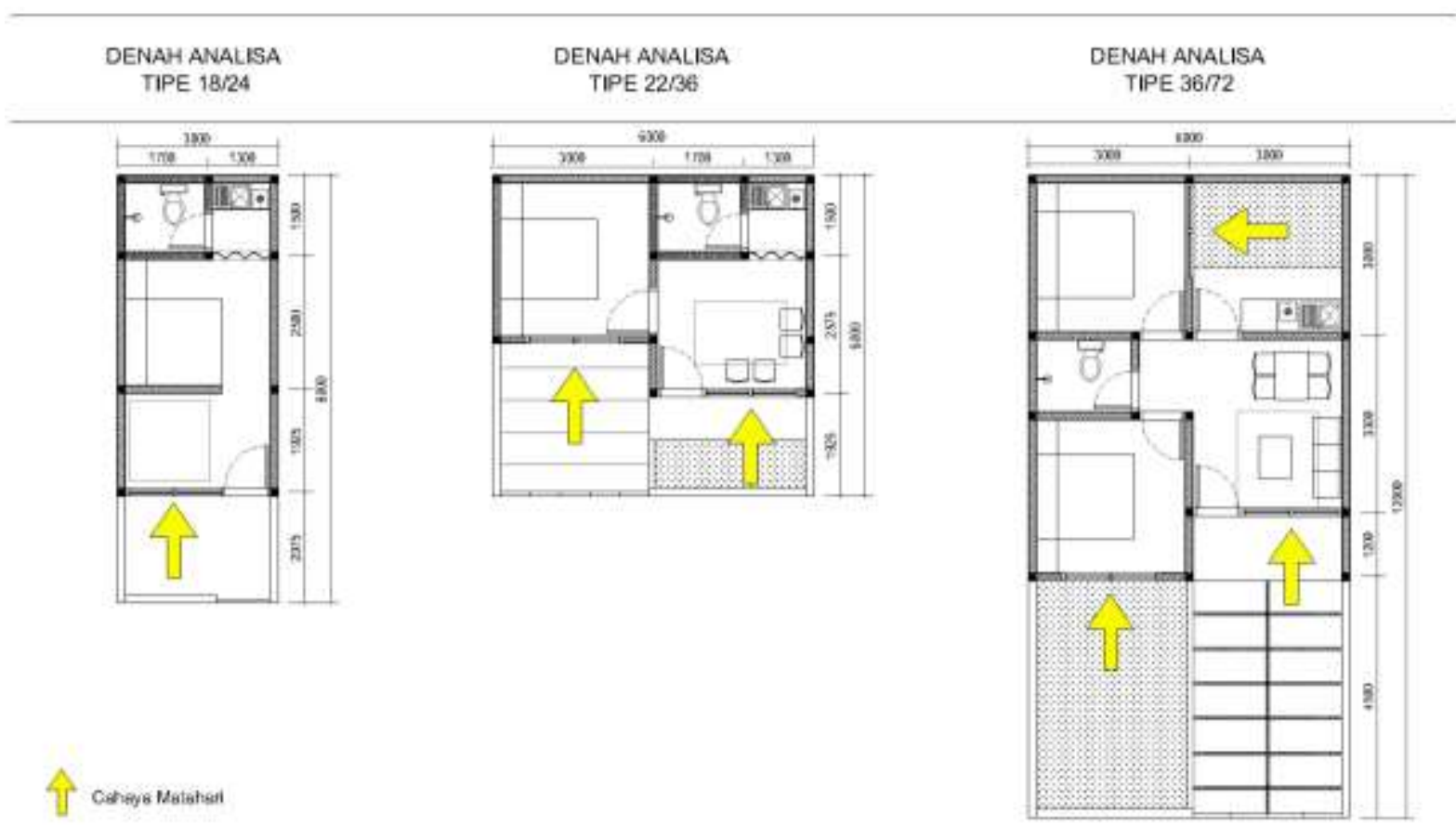

Sumber : Peneliti, 2020

\section{Analisa Tipe 18/24 (Pencahayaan \& Penghawaan)}

- Dari analisa didapat bahwa pencahayaan alami tipe 18/24 hanya berada di ruang tamu, sedangkan ruang tidur dan dapur hanya mendapat pencahayaan buatan.

- Bukaan pada tipe 18/24 sebesar $4.5 \mathrm{~m}^{2}$ atau $25 \%$ dari luas lantai, lebih besar dari standar Kepmenkes No.829/Menkes/SK/VII/1999 sebesar $10 \%$.

- Data analisa penghawaan, area kamar tidur, kamar mandi dan dapur tidak mendapat penghawaan sama sekali.

- Area dapur tidak ada sarana pembuangan asap, sehingga asap yang dihasilkan ketika memasak tidak langsung terbuang keluar ruangan.
Analisa Tipe 22/36 (Pencahayaan \& Penghawaan)

- Dari analisa tipe 22/36 seluruh ruangan mendapat pencahayaan alami, hanya area dapur yang mendapatkan cahaya buatan.

- Bukaan pada tipe 22/36 sebesar $7.2 \mathrm{~m}^{2}$ atau $32.7 \%$ dari luas lantai, lebih besar dari standar Kepmenkes No.829/Menkes/SK/VII/1999 sebesar $10 \%$.

- Data analisa penghawaan, ruang tamu dan ruang tidur mendapat penghawaan dari bukaan jendela dan pintu.

- Area dapur dan kamar mandi tidak mendapat penghawaan.

- Area dapur tidak ada sarana pembuangan asap. 
Analisa Tipe 36/72 (Pencahayaan \& Penghawaan)

- Dari analisa tipe 36/72 seluruh area mendapat pencahayaan alami, hanya area kamar mandi yang mendapat pencahayaan buatan.

- Bukaan pada tipe 36/72 sebesar $10 \mathrm{~m}^{2}$ atau $27.7 \%$ dari luas lantai, lebih besar dari standar Kepmenkes No.829/Menkes/SK/VII/1999 sebesar $10 \%$.

- Data analisa existing penghawaan seluruh ruangan mendapat penghawaan yang baik dengan adanya bukaan jendela dan pintu.

- Sarana pembuangan asap area dapur cukup baik, posisi dapur berada dibelakang bangunan yang terbuka sehingga asap yang ditimbulkan tidak masuk ke dalam bangunan.

\section{Kenyamanan Ruang Berdasarkan Penataan Sirkulasi dan Perabot}

Menurut Francis D.K. Ching dalam bukunya Teori Arsitektur (1993), alur sirkulasi dapat diartikan sebagai "tali" yang mengikat ruang-ruang suatu bangunan atau suatu deretan ruang-ruang dalam maupun luar, menjadi saling berhubungan.

Sirkulasi menjadi hal penting dalam rumah sederhana karena minimnya luasan yang tersedia dan harus digunakan bersamasama. Sebaiknya penataan sirkulasi ditentukan pada tahap desain, sehingga ruang-ruang yang digunakan bisa tertata rapih dengan fungsi dan penataan perabot. Untuk rumah dengan luasan minimal sebaiknya dipilih sirkulasi yang langsung menuju ruang dengan tetap mempertimbangkan privasi penghuninya.
Sirkulasi juga harus mempertimbangkan letak bukaan (pintu jendela).

Menurut Pedoman Umum Rumah Sederhana Sehat (Nomor 403/KPTS/2002 Keputusan Menteri Kimpraswil 2002 tentang RSH) standar luas lantai per jiwa Minimal 7,2 $\mathrm{m}^{2}$, sedangkan luas lantai per jiwa Indonesia $9 \mathrm{~m}^{2}$.

Tabel 3. Standar Luas Lantai Per Jiwa

\begin{tabular}{l|ccc|} 
& $\begin{array}{c}\text { Standar } \\
\text { /jiwa } \\
\left(\mathrm{m}^{2}\right)\end{array}$ & $\begin{array}{c}\text { Unit } \\
\text { rumah } \\
\left(\mathrm{m}^{2}\right)\end{array}$ & $\begin{array}{c}\text { Luas } \\
\text { lahan } \\
\left(\mathrm{m}^{2}\right)\end{array}$ \\
\hline Minimal & 7,2 & 28,8 & 60 \\
Indonesia & 9 & 36 & 60 \\
International & 12 & 48 & 60
\end{tabular}

Sumber: Pedoman Umum Rumah Sederhana Sehat (Nomor 403/KPTS/2002 Keputusan Menteri Kimpraswil 2002 tentang RSH)

Perabot atau furnitur merupakan hal yang penting dalam rumah sederhana. Pemilihan perabot dan perletakannya yang tepat akan membuat ruang gerak yang cukup sehingga membuat pengguna merasa nyaman. Begitu pula sebaliknya pemilihan dan penataan perabot yang salah akan berpengaruh pada kenyamanan dalam ruang.

Pada 3 tipe rumah yang diteliti dapat dilihat sirkulasi sudah terintegrasi cukup baik antara sirkulasi keluar masuk rumah dan sirkulasi tiap ruangnya. Penataan perabot sudah diletakkan sesuai fungsi dan berada pada sisi bangunan dengan mempertimbangkan letak bukaan. Permasalahan sirkulasi dan penataan perabot terdapat pada tipe 36/72, Di mana fungsi ruang makan, tamu dan keluarga menjadi satu, sehingga sirkulasi pada ruang ini tidak nyaman, dengan penempatan perabot yang buruk. Solusinya dengan membeli perabot yang bisa dilipat dan disimpan. 
Tabel 4. Analisa Sirkulasi dan Perabot 3 tipe Rumah Tangga di DKI Jakarta.

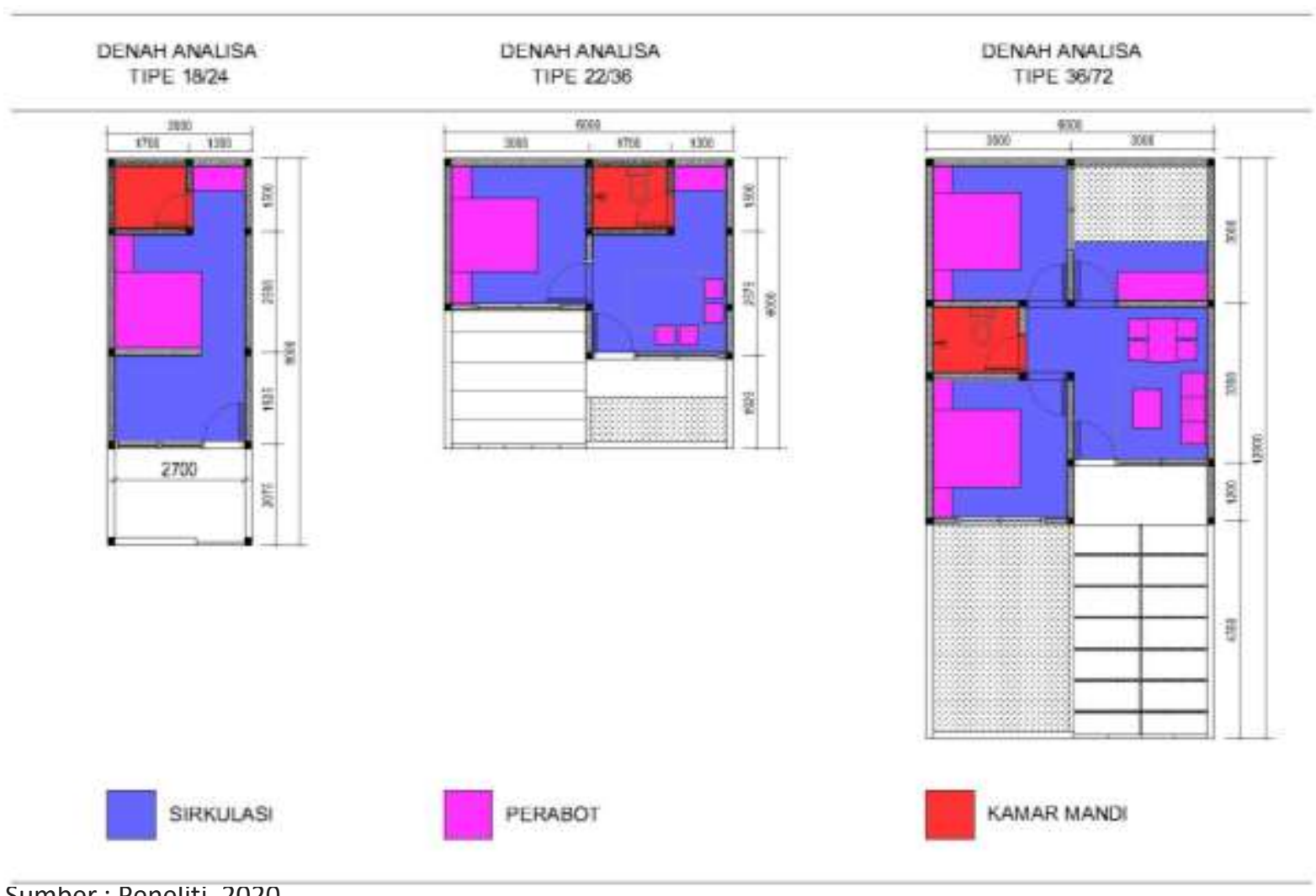

\section{Analisa Tipe 18/24 (Sirkulasi \& Perabot)}

- Analisa sirkulasi tipe $18 / 24$ hanya terdapat 1 akses pintu masuk dan 1 akses ke kamar mandi.

- Sirkulasi menuju ruang berbentuk memanjang seperti koridor, sehingga akses ke setiap ruang hanya melalui satu sirkulasi.

- Total luas sirkulasi bangunan tipe 18/24 adalah $9 \mathrm{~m}^{2}$ atau 50\% dari luas lantai.

- Analisa penataan perabot tipe 18/24 terdapat kasur di ruang tidur dan lemari makan di dapur.

- Analisa rumah tipe $18 / 24$ terkait penataan perabot, tidak banyak penggunaan perabot di dalam rumah, akses menuju ruang tidak terhalangi oleh perabot.
- Total luas perabot pada bangunan tipe $18 / 24$ adalah $3.7 \mathrm{~m}^{2}$ atau $20.5 \%$ dari luas lantai.

\section{Analisa Tipe 22/36 (Sirkulasi \& Perabot)}

- Analisa sirkulasi tipe 22/36 terdapat 1 akses pintu masuk ke bangunan, 1 akses ke kamar tidur dan 1 akses ke kamar mandi.

- Sirkulasi pada tipe 22/36 terpusat pada ruang tamu/keluarga, sehingga ruang keluarga, dapur dan kamar mandi bisa langsung di akses.

- Total luas sirkulasi bangunan tipe 22/36 adalah $12,5 \mathrm{~m}^{2}$ atau $56.8 \%$ dari luas lantai.

- Analisa penataan perabot tipe 22/36 terdapat kursi lipat di ruang 
tamu/keluarga, kasur di ruang tidur, dan lemari makan di dapur.

- Analisa rumah tipe 22/36 terkait penataan perabot cukup baik, akses menuju ruang tidur dan dapur tidak terhalangi oleh perabot.

- Total luas perabot pada bangunan tipe 22/36 adalah $4.3 \mathrm{~m}^{2}$ atau $19.7 \%$ dari luas lantai.

\section{Analisa Tipe 36/72 (Sirkulasi \& Perabot)}

- Analisa sirkulasi tipe $36 / 72$ terdapat 1 akses pintu masuk ke bangunan, 2 akses kamar tidur, 1 akses kamar mandi dan 1 akses pintu belakang menuju taman \& dapur.

- Sirkulasi pada tipe 36/72 terpusat pada ruang tamu/keluarga, sehingga 2 ruang tidur, 1 kamar mandi dan dapur bisa langsung di akses.

- Total luas sirkulasi bangunan tipe 36/72 adalah $21,5 \mathrm{~m}^{2}$ atau $59.7 \%$ dari luas lantai.

- Analisa penataan perabot tipe $36 / 72$ terdapat 1 sofa, 1 meja kecil di ruang tamu/keluarga, 1 meja makan, 4 kursi lipat di ruang tamu/keluarga, 2 kasur di ruang tidur dan 1 lemari makan di dapur.

- Analisa rumah tipe 36/72 terkait penataan perabot kurang baik, penataan meja dan kursi makan yang kurang ditata dengan baik, sehingga sirkulasi menuju kamar tidur dan kamar mandi menjadi sempit.

- Total luas perabot pada bangunan tipe $36 / 72$ adalah $10.2 \mathrm{~m}^{2}$ atau $28.3 \%$ dari luas lantai.

Tabel 5. Analisa Standar Sirkulasi /Jiwa dan Luas Perabot

\begin{tabular}{lcccc} 
& $\begin{array}{c}\text { Standar } / \text { jiwa } \\
\left(\mathrm{m}^{2}\right)\end{array}$ & Luas Perabot $\left(\mathrm{m}^{2}\right)$ & Unit rumah $\left(\mathrm{m}^{2}\right)$ & Luas lahan $\left(\mathrm{m}^{2}\right)$ \\
\hline Minimal & 7,2 & - & 28,8 & 60 \\
Indonesia & 9 & - & 36 & 60 \\
Tipe 18/24 & 9 & 3.7 & 18 & 24 \\
Tipe 22/36 & 12.5 & 4.3 & 22 & 36 \\
Tipe 36/72 & 21.5 & 10.2 & 36 & 72 \\
\hline
\end{tabular}

Dari tabel 5 dapat dilihat bahwa 3 tipe bangunan tumah tangga di DKI Jakarta, secara luas sirkulasi sudah memenuhi standard luas lantai per jiwa menurut Pedoman Umum Rumah Sederhana Sehat (Nomor 403/KPTS/2002 Keputusan Menteri Kimpraswil 2002 tentang RSH), di mana standard jiwa $/ \mathrm{m}^{2}$ Indonesia adalah $9 \mathrm{~m}^{2}$. Sirkulasi jiwa/ $\mathrm{m}^{2}$ rumah tangga tipe $18 / 24$ yaitu sebesar $9 \mathrm{~m}^{2}$ atau $50 \%$ dari luas lantai dan luas perabot adalah $3.7 \mathrm{~m}^{2}$ atau $20.5 \%$ dari luas lantai. Sedangkan pada tipe 22/36 luas sirkulasi jiwa $/ \mathrm{m}^{2}$ adalah $12.5 \mathrm{~m}^{2}$ atau $56.8 \%$ dan luas perabot sebesar $4.3 \mathrm{~m}^{2}$ atau $19.7 \%$. Pada tipe $36 / 72$ luas sirkulasi jiwa/m² adalah $21.5 \mathrm{~m}^{2}$ atau $59.7 \mathrm{~m}^{2}$ dan luas perabot $10.2 \mathrm{~m}^{2}$ atau $28.3 \%$ dari luas lantai.

\section{KESIMPULAN}

Dari penelitian yang dilakukan, maka dapat disimpulkan bahwa:

a. Pencahayaan dan penghawaan pada tipe 18/24 sudah sesuai standard Kepmenkes, 1999. 
b. Pencahayaan ruang tidur dan kamar mandi pada tipe 18/24 menggunakan pencahayaan buatan.

c. Tipe 18/24 tidak ada sarana pembuangan asap pada area dapur, tidak sesuai standard Kepmenkes, 1999.

d. Sirkulasi pada tipe 18/24 adalah $9 \mathrm{~m}^{2}$ atau $50 \%$ dari luas lantai.

e. Penataan perabot pada tipe 18/24 berada di ruang tidur dan dapur, sehingga luas perabot pada tipe 18/24 adalah $3.7 \mathrm{~m}^{2}$ atau $20.5 \%$ dari luas lantai.

f. Pencahayaan dan penghawaan pada tipe 22/36 sudah sesuai standard Kepmenkes, 1999.

g. Pencahayaan kamar mandi dan dapur pada tipe 22/36 menggunakan pencahayaan buatan.

h. Tipe 22/36 tidak ada sarana pembuangan asap pada area dapur, tidak sesuai standard Kepmenkes, 1999.

i. Sirkulasi pada tipe $22 / 36$ adalah 12.5 $\mathrm{m}^{2}$ atau $56.8 \%$ dari luas lantai.

j. Penataan perabot pada tipe 22/36 berada pada ruang tamu dan kamar tidur, luas perabot pada tipe 22/36 adalah $4.3 \mathrm{~m}^{2}$ atau $19.7 \%$ dari luas lantai.

k. Pencahayaan dan penghawaan pada tipe 36/72 sudah sesuai standard Kepmenkes, 1999.

I. Seluruh ruangan pada tipe $36 / 72$ mendapat pencahayaan alami.

m. Tipe 36/72 mempunyai sarana pembuangan asap pada area dapur, yang berada di belakang rumah yang terbuka.

n. Sirkulasi tipe 36/72 adalah $21.5 \mathrm{~m}^{2}$ atau $59.7 \%$ dari luas lantai.

o. Penataan perabot tipe $36 / 72$ berada pada ruang keluarga dan ruang tidur, luas perabot pada tipe 36/72 adalah $10.2 \mathrm{~m}^{2}$ atau $28.3 \%$ dari luas lantai.
Penelitian ini terbatas dalam pengambilan data berupa data pengukuran penghawaan dan pencahayaan maka dalam penelitian berikutnya kenyamanan ruang bisa dikaji dari sisi pencahayaan, penghawaan, luas lantai dan konsep desain agar bisa diciptakan sebuah rekomendasi kenyaman ruang secara menyeluruh.

\section{DAFTAR PUSTAKA}

Delyuzir, R. D., \& Murni, A. (2019). Kenyamanan Termal Bangunan Sekolah Dasar Negeri (Studi Kasus: Sekolah Dasar Negeri 02 Ulujami Pagi, Jakarta). Vitruvian vol. 8 no. 2, 75-80. http://dx.doi.org/10.22441/vitruvian. 2018.v8i2.003

Dora, P.E. \& Nilasari, P.F., 2011. Pemanfaatan Pencahayaan Alami pada Rumah Tinggal Tipe Townhouse di Surabaya. http://repository. petra.ac.id/id/eprint/15247

Ching, Francis D.K. 1993. Arsitektur : Bentuk Ruang dan Tatanan (edisi Kedua). Erlangga. Jakarta.

Karyono, Tri H. 1999. Kenyamanan Suhu Dalam Arsitektur Tropis.

Kasjono, HS. 2011. Penyehat Pemukiman. Yogyakarta: Gosyen Publishing.

KBBI, 2016. Kamus Besar Bahasa Indonesia (KBBI).

Keputusan Menteri Kesehatan Republik Indonesia. 1999. No.829/Menkes/SK/VII/1999 tentang Persyarataan Kesehatan Perumahan. Jakarta.

Keputusan Menteri Permukiman dan

Prasarana Wilayah Republik Indonesia. 2002. Nomor 403/KPTS/2002 tentang Pedoman Umum Rumah Sederhana Sehat. Jakarta.

Kusumaningrum, A., \& Martiningrum, I. (2017). Persepsi Pengunjung terhadap Tingkat Kenyamanan Bangunan Pelayanan Kesehatan (Studi Kasus RSIA Melati Husada Kota 
Malang). Jurnal Mahasiswa Jurusan Arsitektur Vol. 5 No. 4. http://arsitektur.studentjournal. ub.ac.id/index.php/jma/article/view/429/409

Oktavia, Tantri. 2010. Fisika Bangunan.

Malang: Bayumedia Publishing.

Pemerintah Indonesia. 2002. Undang-Undang Republik Indonesia No. 28 Tahun 2002 tentang Bangunan Gedung. Sekretariat Negara. Jakarta.

Putra, I. I. 2019 Statistik Perumahan DKI Jakarta tahun 2019. http://statistik.jakarta. go.id/statistik-perumahan-dki-jakarta-tahun2019/ (diakses 25 september 2020).

Suryo, M. S. (2017). Analisa Kebutuhan Luas Minimal Pada Rumah Sederhana Tapak Di Indonesia. Jurnal Permukiman Vol. 12 No. 2, 116-123. $\quad$ http://dx.doi.org/10.31815/ jp. $2017.12 .116 \% 20-\% 20123$

Satwiko, Prasasto. 2009, Fisika Bangunan, Yogyakarta. 